\title{
Maatalouden investoinnit ja niiden vaikutus 1987-2000
}

\author{
Erik Haggrén ja Heikki Mäkinen \\ Helsingin yliopisto, Taloustieteen laitos, PL 27, 00014 Helsingin Yliopisto \\ Erik.Haggren@Helsinki.Fi, Heikki.Makinen@Helsinki.Fi
}

\section{Johdanto}

Helsingin Yliopiston taloustieteen laitoksessa on tutkittu maatalouden taloudellista sopeutumista maamme EU-jäsenyyden aikana. Aihepiiriä koskeva laaja, koko maan tilastoaineistoon ja mallilaskelmiin pohjautuva peruskartoitus tehtiin Suomen Akatemian rahoittamassa tutkimusprojektissa, jonka loppuraportissa "Maatalousyritysten talous vuosina 1993-2002" (Sipiläinen ym. 1998) esitettyjä tuloksia käytettiin maaliskuussa 1998 eduskunnassa esitetyn välikysymyksen keskeisinä perusteluina.

Tuon tutkimuksen keskeisiä tuloksia oli se, että suuri osa EU-jäsenyyden ensimmäisten vuosien aikana tapahtuneesta maataloustulon kehityksestä selittyi poistojen ja korkomenojen pienenemisellä. Muutoin maataloustulo olisi laskenut selvästi nopeammin. Kuitenkin maatalouden tuotantorakenteen kehittäminen edellyttää mittavia investointeja jatkavien tilojen tuotantokapasiteetin uusimiseksi ja laajentamiseksi.

Tämän tutkimuksen tavoitteena on aluksi tutkia maatalouden investointien kehitystä EU-jäsenyyden aikana ja verrata sitä ennen EU-jäsenyyttä toteutuneeseen kehitykseen. Tämä tarkastelu tehdään alueittain, tuotantosuunnittain ja tilakokoluokittain.

Tavoitteena on myös tutkia, miten investoinnit ovat vaikuttaneet maatalouden sopeutumiseen ja tulokehitykseen EU-jäsenyyden aikana eri tilaryhmissä (alue, tuotantosuunta, tilakoko).

Tässä esitelmässä esitetty tarkastelu perustuu Taloustieteen laitoksella suoritettavaan tutkimusprojektiin, joka on edennyt loppuvaiheeseen. Esitelmässä pyritään tarkastelemaan eräitä tässä vaiheessa esiin tulleita, keskeisiä ja mielenkiintoisia tutkimustuloksia, mutta projektin ja aihepiirin laajuuden vuoksi niitä voidaan käydä läpi vain hyvin yleisellä tasolla käytettävissä olevan ajan ja sivumäärän puitteissa.

\section{Aineisto ja menetelmät}

Tutkimus perustuu ensisijaisesti Tilastokeskuksen Maatalouden yritys- ja tulotilaston MYTT vuosien 1987-2000 perusaineistoihin, joista on muodostettu yhtenäiset aikasarjat. Aineisto perustuu otoksiin, joiden tilamäärä on laskenut vuoden 1987 noin 15000 tilasta koko maan tilaluvun laskun myötä vuoden 2000 noin 9000 tilaan. Otostilojen tiedot voidaan tilastollisesti ulottaa koskemaan maan kaikkia tiloja eri tavoin luokitelluissa tilaryhmissä. Tilakohtaisen ja tilastollisesti edustavan aineiston käyttö mahdollistaa kokonaisaineistoja yksityiskohtaisemman kehityksen arvioinnin ja myös jakaumatietojen hyväksikäytön.

Tutkimuksen keskeisenä teoreettisena viitekehikkona on investointiteoria. Tutkimuksen tässä vaiheessa ei kuitenkaan ole analysoitu ekonometrisin menetelmin investointien ja niihin vaikuttavien tekijöiden yhteyksiä, vaan keskeiset kehityspiirteet on esitetty aikasarjakuvaajien avulla.

\section{Tarkastellut muuttujat}

Tutkimuksessa MYTT-aineiston verotustietoihin perustuvat muuttujat on muokattu yhdenmukaisiksi koko jakson ajalta. Keskeisten muuttujien tietosisältö muodostuu seuraavasti:

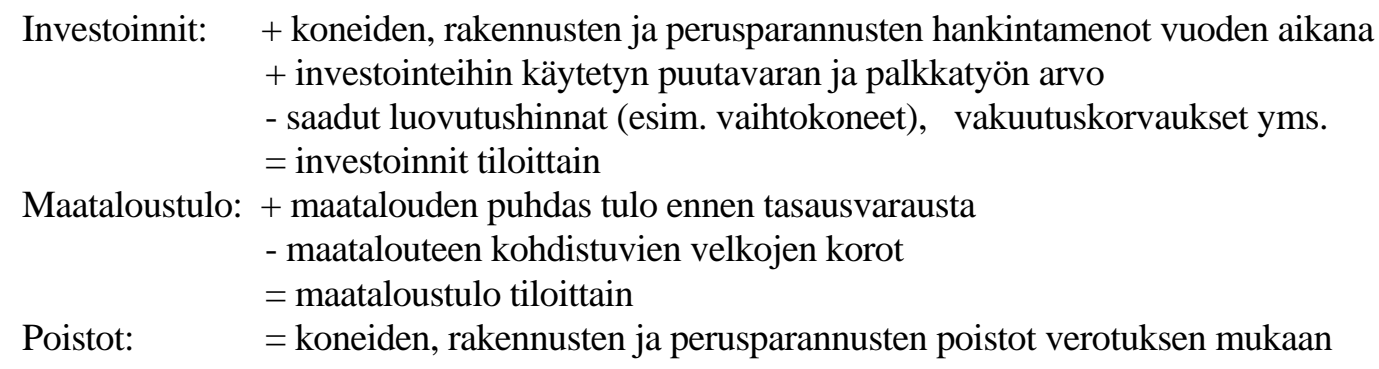

Hehtaarikohtaiset luvut on laskettu kunakin vuonna tilalla viljelyksessä ollutta pinta-alaa kohti. Markkamääräiset luvut on ilmaistu vuoden 2000 hinnoin. Tutkimuksessa oli ongelmana vuoden 1992 puutteellinen MYTT-aineisto, jossa ei ole investointeja koskevia tietoja. Tarvittaessa mm. kuvioissa puuttuvat arvot on korvattu vuosien 1991 ja 1993 keskiarvoilla. Alueluokitteluna on käytetty EU-tukialuejakoa, jossa B1, 
B2 ja BS on yhdistetty yhdeksi B-alueeksi. Samoin C2p, C3 ja C4 -alueet on yhdistetty C-pohjoinen alueeksi (C2P-).

Tutkimuksen keskeisenä lähtökohtana ovat maatalouden yritystalouden ja kannattavuustutkimuksen peruskäsitteet ja niiden analysoinnissa käytetyt tutkimusmenetelmät. Erityisen mielenkiintoisia ovat tilasuuruusluokittaiset tulokset, joiden avulla voidaan tarkastella tilaryhmien taloudellista tulosta keskiarvoharhasta ainakin osittain puhdistettuna ja investointien vaikutusta siihen.

\section{Tulokset ja tulosten tarkastelu}

Koska tutkimus on osin vielä kesken, tässä vaiheessa voidaan esittää vasta alustavia tutkimustuloksia. Tulosten oikeellisuutta on varmistettu mm. vertaamalla niitä julkaistuihin tilastotietoihin.

Maatalouden investoinnit supistuivat voimakkaasti kaikissa tilaryhmissä ja maan kaikilla alueilla 1990luvun alkupuolella (kuviot 1, 3 ja 4). Tähän vaikuttivat sekä yleistaloudellinen lama että maatalouden kannattavuusnäkymien heikentyminen ja epävarmuuden lisääntyminen mm. EU-jäsenyysneuvottelujen myötä. Keskimäärin tilakohtaiset investoinnit puolittuivat vuoden 1990 huipusta eli 40000 markan tasolta noin 20000 markkaan vuoteen 1994 mennessä.

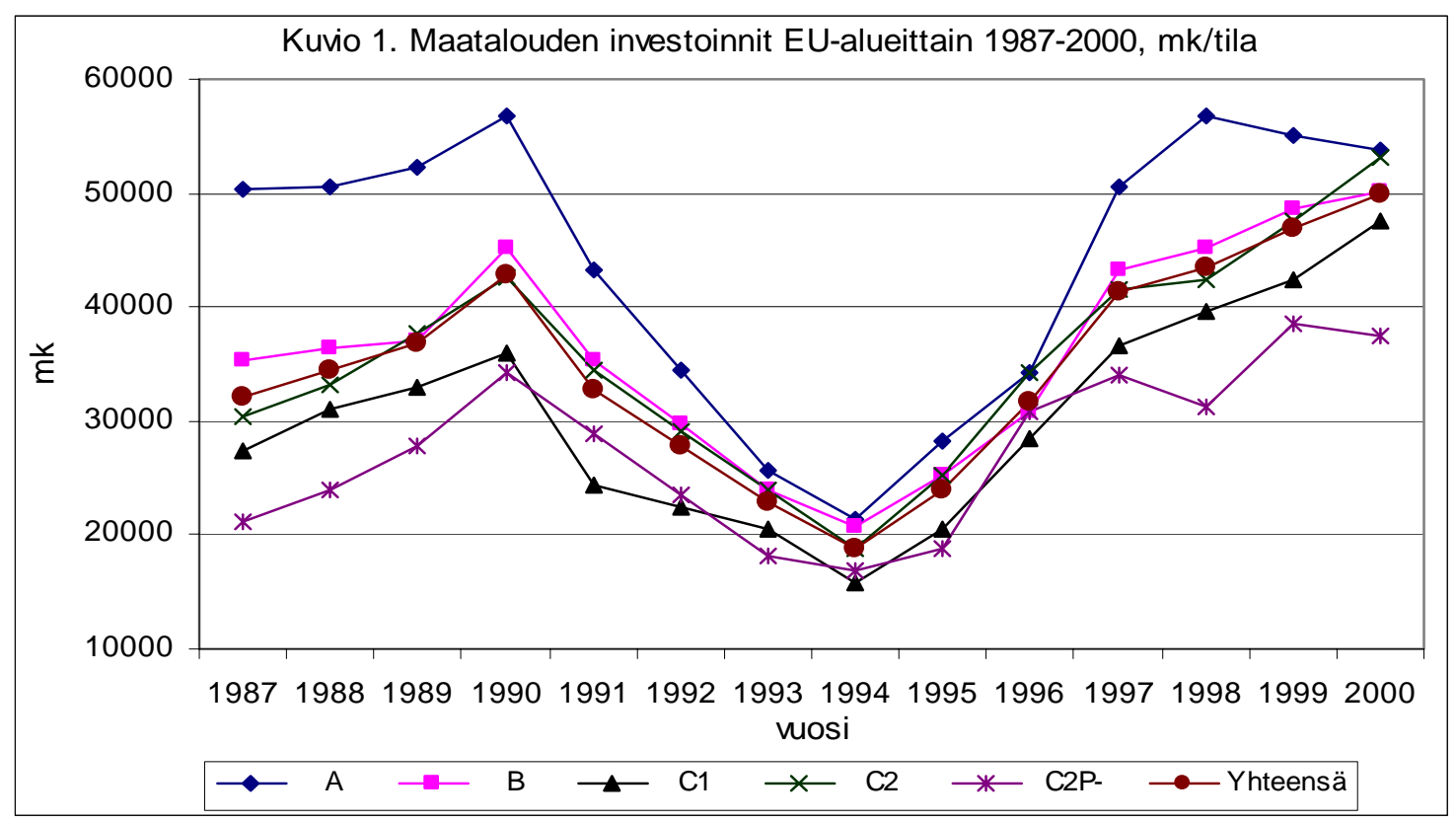

Suomen liityttyä EU:n jäseneksi vuoden 1995 alussa tilanne kääntyi päinvastaiseksi. Keskimääräiset investoinnit kasvoivat nopeasti 50000 markan tasolle vuoteen 2000 mennessä. Tähän vaikuttivat erityisesti EU-tukijärjestelmien mittavat investointituet, joilla pyrittiin kehittämään Suomen maatalouden rakennetta lähemmäs vanhojen EU-maiden tasoa.

Investointien voimakas kasvu EU-jäsenyyden myötä muutti maataloussektorin kehityskuvan myönteiseksi. Koko 1990-luvun alun tilat olivat keskimäärin taantuneet ja pahimmillaan investointien ja poistojen suhde laski vuonna 1994 tasolle 0.8. Tämä merkitsi sitä, että investoinnit eivät enää riittäneet tuotantopääoman ylläpitämiseen, vaan maatilat "söivät pääomiaan”. Heti EU-jäsenyyden alussa suhde alkoi nopeasti nousta ja vaihteli tarkastelujakson lopulla välillä 1.4-1.8 tuotantosuunnasta riippuen.

Vaikka investointikehityksen yleiskuva ennen ja jälkeen EU-jäsenyyden on ollut peruspiirteiltään samantapainen useimmissa tilaryhmissä ja eri alueilla, niin kuitenkin eräät selkeät maataloussektoria muokkaavat kehityspiirteet tulevat tutkimusjakson aikana esille. 


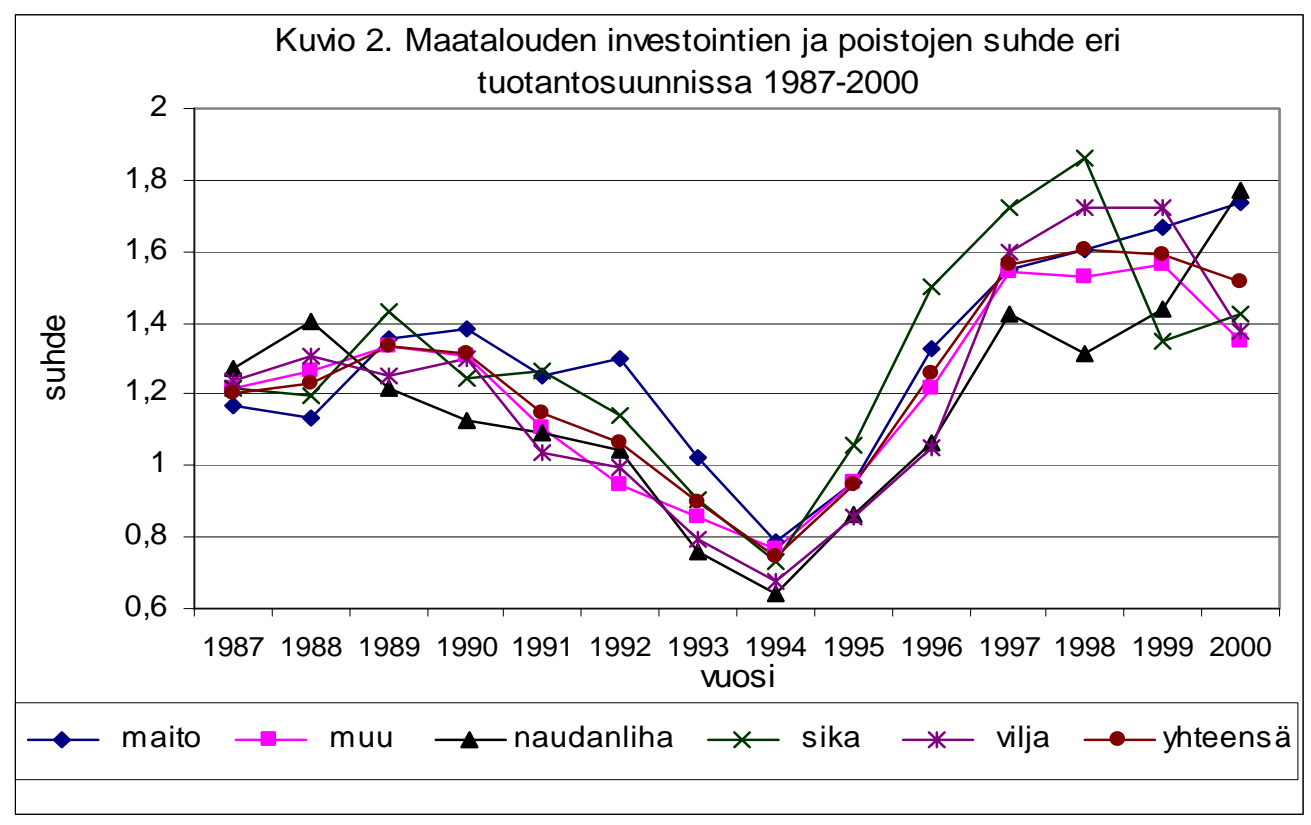

Erityisesti EU-jäsenyyden ensimmäisinä vuosina investointeja tekevien tilojen määrän lasku tasaantui vajaan 50000 tilan tasolle, joten investoivien tilojen suhteellinen osuus kaikista tiloista kasvoi. Sittemmin investoivien tilojen luku on taas alkanut uudelleen laskea.

Viime vuosina investoinnit ovat myös aiempaa selvemmin keskittyneet suurimpiin tilakokoluokkiin. Kuviossa 3 keskittyminen näkyy esimerkiksi maitotiloilla erityisesti siten, että pienimpien tilojen investoinnit ovat pysyneet ennallaan tai jopa laskeneet. Samalla kaikkien maitotilojen keskimääräiset investoinnit kasvavat trendinomaisesti, vaikka vastaavaa kasvutrendiä ei näy yhdessäkään kokoluokassa.

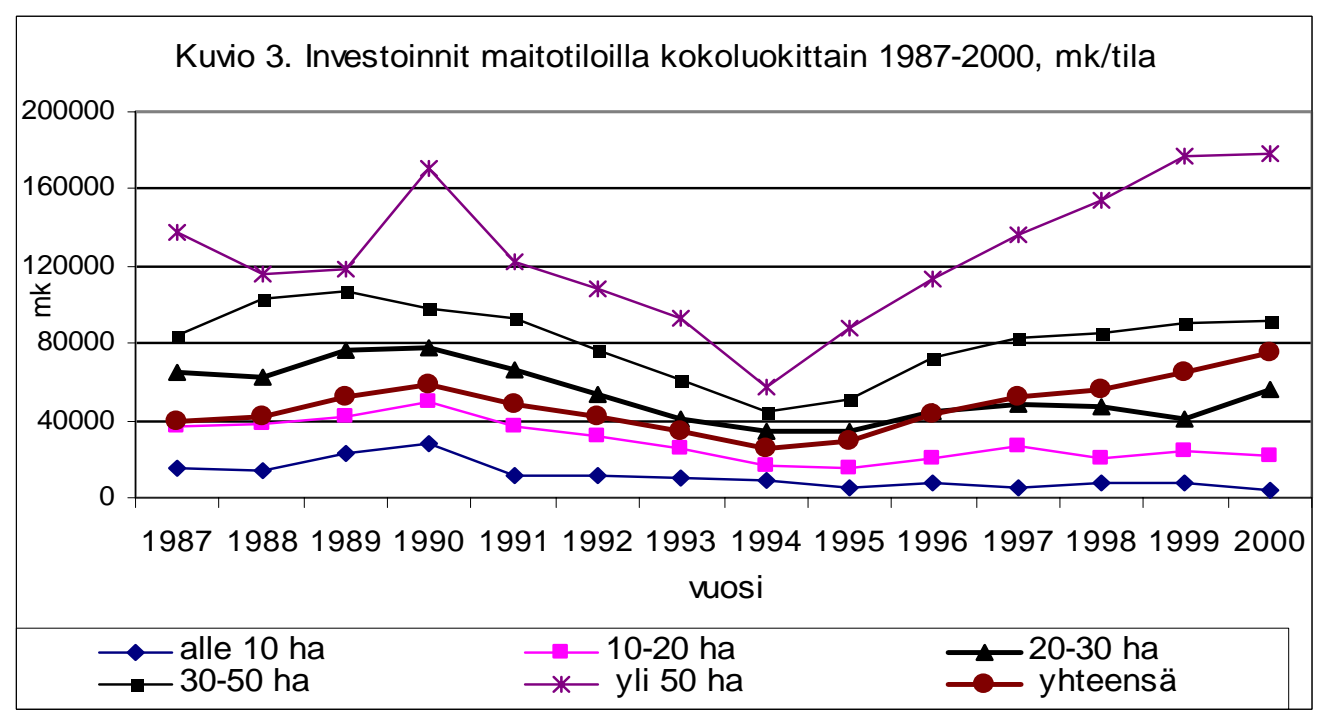

Tuotantosuunnista sikatilat ovat perinteisesti investoineet voimakkaimmin (kuvio 4), mutta EUjäsenyyden myötä maitotilat näyttäisivät vahvistavan asemiaan. Viljatilojen investoinnit eivät ole kehittyneet EU-jäsenyyden aikana yhtä voimakkaasti kuin maito- ja sikatiloilla paria ensimmäistä vuotta lukuun ottamatta.

Alueittain tarkasteltuna eteläisen Suomen tilat A- ja B-alueilla ovat perinteisesti investoineet eniten (kuvio 1), mutta aivan viime vuosina erityisesti Pohjanmaan tilat C2 -alueella ovat nousseet lähes samalle tasolle. Sitä vastoin muualla maan pohjoisosissa (C2P- -alue) investoinnit eivät ole kehittyneet yhtä voimakkaasti. 


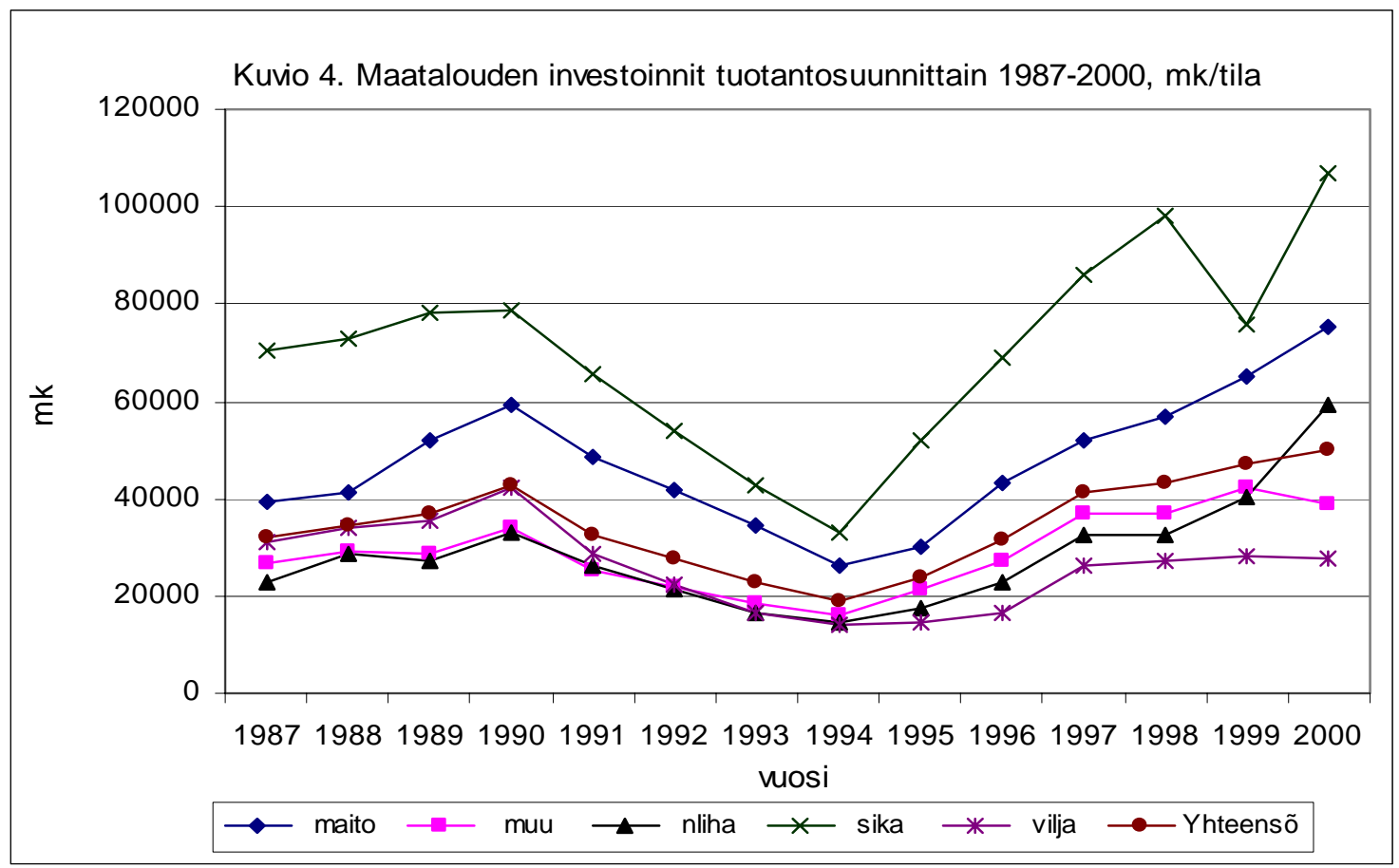

Investointien vaikutus maataloustuloon vaatisi yksityiskohtaista tutkimusta, mutta yleensä tulo- ja kannattavuusedellytyksiltään parhaat tilat investoivat eniten. Tarkasteltaessa maataloustulon kehitystä eri EU-tukialueilla tulee erityisenä kehityspiirteenä esiin tulojen tasoittuminen alueitten välillä. Eteläisillä Aja B- alueilla reaalinen maataloustulo on pysynyt trendinomaisesti lähes ennallaan koko tarkastelujakson ajan, kun taas pohjoisempien alueiden maataloustulo on kasvanut, selvimmin pohjoisimmalla C2P- alueella.

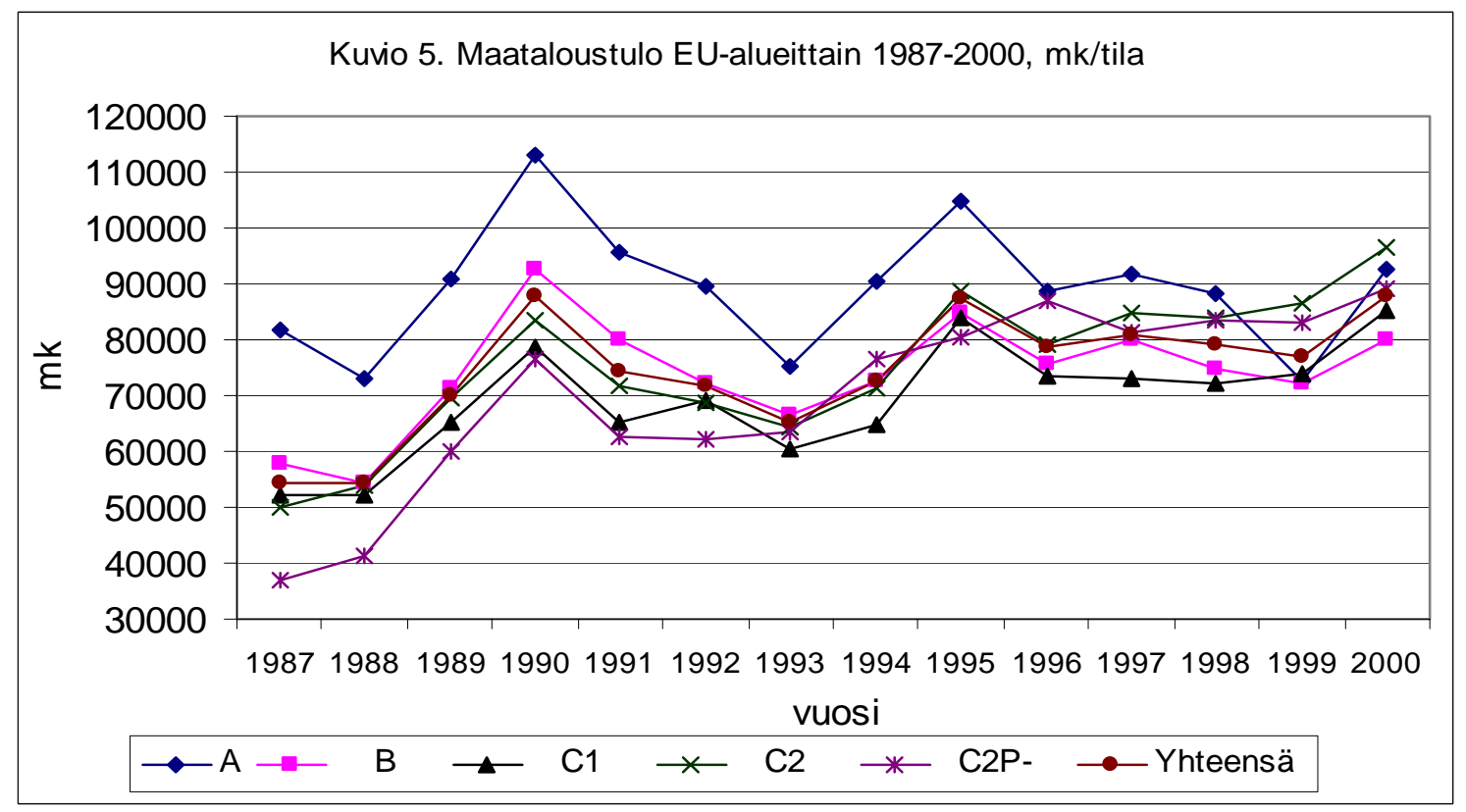

\section{Johtopäätökset}

Maatalouden investoinnit ovat EU-jäsenyyden myötä nousseet 1990-luvun alkupuolen lamasta tasolle, joka on selvästi nopeuttanut myös maatalouden rakennekehitystä EU:n maatalouspoliittisten tavoitteiden mukaisesti. Keskimäärin investoinnit ovat tarkastelujakson lopussa eri alueilla ja eri tuotantosuunnissa tasolla, jolla investoinnit ovat selvästi poistoja suurempia eli tuotantorakenne kehittyy. 
Käytettävissä oleva aikasarja EU-jäsenyyden ajalta on liian lyhyt, jotta investointien vaikutus maataloustuloon ehtisi tulla selvästi esiin. Lisäksi verotusaineiston avulla on vaikea tutkia investointien ja maataloustulon yhteyttä. Näyttää kuitenkin siltä, että maatalouden kehitys on ollut myönteisempää kuin jäsenyyden ensimmäisten vuosien perusteella tehdyt tutkimustulokset ennustivat. Toisaalta myös esim. Agenda 2000 ratkaisussa kyettiin parantamaan maatalouden hinta- ja tukipolitiikkaa eräiltä osin Suomen kannalta aiempaa oikeudenmukaisempaan suuntaan.

\section{Kirjallisuus}

Sipiläinen, T., Ryhänen, M, Ylätalo, M., Haggrén, E., \& Seppälä. E. 1998. Maatalousyritysten talous vuosina 1993-2002. -EU-jäsenyyden vaikutus tuloihin ja kannattavuuteen. Helsingin yliopisto, Taloustieteen laitos, Julkaisuja 18. 